\title{
MODEL AIR (AUDITORY, INTELLECTUALLY, REPETITION) DENGAN STRATEGI PENINJAUAN KEMBALI UNTUK MENINGKATKAN KREATIVITAS DAN KEAKTIFAN SISWA DI SMA YASMIDA KEC. AMBARAWA KAB. PRINGSEWU
}

\author{
Muhtarom, Dwi Rohmadi Mustofa, Muhammad Idris \\ Jl. Raya Wonokriyo Gadingrejo Pringsewu \\ Email: stitpringsewu@gmail.com
}

\begin{abstract}
This study aims to improve creativity and student learning outcomes on learning Sociology class $\mathrm{X}$ SMA Yasmida Ambarawa. In general, this research seeks to improve the creativity and learning outcomes of students by using AIR learning model with Review Strategy.

This type of research is Classroom Action Research (PTK). The subjects of this study are the students of grade X SMA Yasmida Ambarawa which amounted to 26 people. The object of this research is the implementation of Sociology learning by using AIR learning model with Review Strategy. Classroom Action Research is done in 2 cycles, each cycle consists of 2 meetings.

The results showed that there is an increase of creativity and Activity of students by applying AIR model learning with Review Strategy. Student creativity is seen from all indicator of creativity and Student Activity is improving. In the first cycle of creativity of $60.66 \%$, in the second cycle of $79.96 \%$, while the student's activity also increased from $70 \%$ to $85 \%$. Creativity can be seen from the ability to generate many ideas, the ability to propose a variety of solutions to problems, the ability to find answers, tend to give more answers, respond to questions posed, have many questions, and be able to describe things in detail. Student activity is seen from observing, asking, trying, reasoning, tasting, and creating. Students can listen, think, share in groups, and review the material with pleasure so as to provide opportunities for students to hone their own ability, responsibility, and self-belief.
\end{abstract}

\begin{abstract}
Abstrak
Penelitian ini bertujuan untuk meningkatkan kreativitas dan hasil belajar siswa pada pembelajaran Sosiologi kelas X SMA Yasmida Ambarawa. Secara umum penelitian ini mengupayakan peningkatan kreativitas dan hasil belajar siswa dengan menggunakan model pembelajaran AIR dengan Strategi Peninjauan Kembali.

Jenis penelitian ini adalah Penelitian Tindakan Kelas (PTK). Subjek penelitian ini adalah siswa kelas X SMA Yasmida Ambarawa yang berjumlah 26 orang. Objek penelitian ini adalah pelaksanaan pembelajaran Sosiologi dengan menggunakan model pembelajaran AIR dengan Strategi Peninjauan Kembali. Penelitian Tindakan Kelas ini terlaksana dalam 2 siklus yang masing-masing siklus terdiri dari 2 pertemuan.

Hasil penelitian menunjukkan bahwa adanya peningkatan kreativitas dan Keaktifan siswa dengan menerapkan pembelajaran model AIR dengan Strategi Peninjauan Kembali. Kreativitas siswa yang dilihat dari semua indikator kreativitas dan Keaktifan siswa mengalami peningkatan. Pada siklus I kreatifitas sebesar 60,66\%, pada siklus II sebesar 79,96\%, sedangkan keaktifan siswa juga mengalami peningkatan dari $70 \%$ menjadi $85 \%$. Kreativitas dapat dilihat dari kemampuan menghasikan banyak gagasan, kemampuan mengemukakan barmacam-macam pemecahan terhadap masalah, kemampuan menemukan jawaban, cenderung memberi jawaban yang lebih banyak, menanggapi pertanyaan yang diajukan, mempunyai banyak pertanyaan, dan mampu menguraikan sesuatu secara terperinci. Keaktifan siswa dilihat dari mengamati, menanya, mencoba, menalar, menyaji, dan mencipta. Siswa dapat menyimak, berfikir, berbagi dalam kelompok, serta mengulas materi dengan senang sehingga memberikan kesempatan kepada siswa untuk mengasah kemampuannya sendiri, bertanggung jawab, dan adanya kepercayaan terhadap diri sendiri.
\end{abstract}

Kata Kunci : Model AIR (Auditory, Intellectually, Repetition), Strategi Peninjauan Kembali, Kreativitas dan Keaktifan. 


\section{A. Pendahuluan}

Sumber Daya Manusia merupakan bagian dari dalam suatu kemajuan ilmu, pembangunan, dan teknologi. Oleh karena itu dalam era sekarang ini manusia dituntut untuk memiliki semangat dan kedisiplinan yang tinggi dalam menjalankan peran dan fungsinya baik untuk individual maupun tujuan organisasional (Prihantoro:2012). Kualitas Sumber Daya Manusia (SDM) merupakan salah satu unsur utama yang harus diasah dan ditingkatkan dalam dunia pendidikan (Herman, 2007). Salah satu hal yang perlu diperbaiki dalam dunia pendidikan Indonesia untuk mencapai pada kualitas sumber daya manusia yang unggul adalah sistem pembelajarannya. Dalam proses pembelajaran, biasanya siswa hanya difokuskan untuk menghafal tanpa dilatih untuk mengasah kemapuan berpikir dan menganalisis masalah (Ningrum, 2016). Sehingga sebagian besar siswa tidak dapat menghubungkan antara ilmu yang mereka dapatkan dengan manfaat ilmu tersebut dalam kehidupan (Sahala dan Samad, 2010). Oleh karena itu diperlukan adanya model pembelajaran inovatif yang dapat meningkatkan keaktifan dan kemampuan berpikir kreatif siswa. Kemampuan berpikir kreatif merupakan proses mental yang digunakan individu untuk memunculkan ide baru Siswono dan Budayasa (2006). Menurut Silver (dalam Amalina \& Siswono:2016) komponen dalam menilai kemampuan berpikir kreatif adalah kefasihan (fluency), fleksibilitas (flexibility), dan kebaruan (novelty).. Kemampuan berpikir kreatif sangat diperlukan sebagai modal menghadapi era global (Yunianta et al, 2012). Kemampuan kemampuan tersebut pada dasarnya bisa dirangsang dengan model pembelajaran yang diterapkan oleh setiap pendidik.

Proses pembelajaran penting untuk mendorong siswa mengkomunikasikan gagasan hasil kreasi dan temuanya kepada siswa lain, guru atau pihak-pihak lain. Dengan demikian, proses pembelajaran memungkinkan siswa bersosialisasi dengan menghargai perbedaan (pendapat, sikap, kemampuan, prestasi) dan berlatih untuk kerjasama. Pembelajaran bukanlah sesuatu yang statis, melainkan suatu konsep yang berkembang sesuai dengan kemajuan ilmu dan teknologi. Dengan demikian, pengertian pembelajaran yang berkaitan dengan sekolah ialah kemampuan dalam mengelola secara operasional dan efesien terhadap komponen-komponen yang berkaitan dengan pembelajaran (Martin Yamin dan Bansu Ansari, 2008: 21-22).

Pembelajaran dapat didefinisikan sebagai komunikasi yang dilakukan oleh guru dan siswa sebagai upaya guru untuk memberikan perubahan atau membentuk tingkah laku siswa. Tujuan pembelajaran adalah untuk membangun gagasan saintifik siswa (Hamdani, 2010: 23). Proses pembelajaran terdiri dari tiga variabel, diantaranya yaitu kondisi, strategi serta hasil dari pembelajaran itu sendiri.

Sejak terbit Permendiknas no 21 tahun 2016 tentang Standar Isi yang mencangkup di dalamnya tentang kurikulum 13 menyatakan bahwa, substansi tujuan pendidikan nasional adalah dalam domain sikap spiritual dan sikap sosial, pengetahuan, dan Keaktifan. Oleh karena itu, Standar Isi dikembangkan untuk menentukan kriteria ruang lingkup dan tingkat kompetensi yang sesuai dengan kompetensi lulusan yang dirumuskan, yakni sikap, pengetahuan, dan Keaktifan. Ketiga kompetensi tersebut memiliki proses pemerolehan yang berbeda. Sikap dibentuk melalui aktivitas-aktivitas: menerima, menjalankan, menghargai, menghayati, dan mengamalkan. Pengetahuan dimiliki melalui aktivitas-aktivitas: mengetahui, memahami, menerapkan, menganalisis, mengevaluasi, dan mencipta. Keaktifan diperoleh melalui aktivitas-aktivitas: mengamati, menanya, mencoba, menalar, menyaji, dan mencipta. Karakteristik kompetensi beserta perbedaan proses pemerolehannya mempengaruhi Standar Isi.

Tingkat Kompetensi dikembangkan berdasarkan kriteria; (1) Tingkat perkembangan peserta didik, (2) Kualifikasi kompetensi Indonesia, (3) Penguasaan kompetensi yang berjenjang. Selain itu Tingkat Kompetensi juga memperhatikan tingkat kerumitan/kompleksitas kompetensi, fungsi satuan pendidikan, dan keterpaduan antar jenjang yang relevan. Untuk menjamin keberlanjutan antar jenjang, Tingkat Kompetensi dimulai dari Tingkat Kompetensi Pendidikan Anak Usia Dini

Sejak dikeluarkanya Kurikulum 13 setiap sekolah diharuskan untuk mengoperasionalkan dan melaksanakan kurikulum tersebut dalam proses pembelajarannya. SMA YASMIDA merupakan salah satu sekolah swasta yang saat ini telah menerapkan K13. Kurikulum di sekolah tersebut ditujukan untuk menciptakan lulusan yang kompeten, cerdas dan dapat memberikan dasar-dasar pengetahuan, Keaktifan, pengalaman belajar yang membangun integritas sosial serta membudayakan dan mewujudkan karakter nasional. Pada kenyataannya, Kurikulum 13 yang dikembangkan di SMA Yasmida Ambarawa ini belum dapat dilakukan secara optimal. Permasalahan tersebut diketahui setelah peneliti melakukan observasi di sekolah tersebut. Salah satu mata pelajaran yang ditemukan permasalahan dalam pelaksanaan Kurikulum 13 adalah mata pelajaran Sosiologi khususnya yang terjadi pada kelas X. Pembelajaran Sosiologi di kelas ini belum berjalan secara optimal. 
Berdasarkan hasil observasi yang dilakukan oleh peneliti dan hasil tanya jawab dengan siswa dan guru mata pelajaran Sosiologi kelas X pada tanggal 11 September 2017, ditemukan beberapa masalah diantaranya : siswa sering lupa terhadap materi yang diajarkan guru, dan metode yang digunakan dalam proses pembelajaran cenderung monoton. Kondisi tersebut menjadikan siswa kurang antusias terhadap materi yang diajarkan, siswa ada yang bicara dan bermain sendiri saat guru menerangkan pelajaran/materi akibatnya banyak siswa kurang faham terhadap materi yang diajarkan. Hasil belajar siswa yang belum mencapai Kriteria Ketuntasan Minimum (KKM). Terbukti dengan adanya 15 siswa dari 26 siswa kelas $\mathrm{X}$ yang nilainya kurang dari 75 $(71 \%)$ serta kurangnya kreativitas dan Keaktifan siswa dalam proses belajar mengajar di kelas. Hal ini diketahui dengan ditemukanya siswa yang belum dapat mempunyai banyak gagasan atau ide dalam menanggapi pertanyaan baik dari guru maupun pertanyaan yang muncul dalam diskusi kelas. Siswa kurang menyukai soal-soal yang sulit serta kurang mampu memberikan jawaban/gagasan secara terperinci.

Permasalahan ini muncul karena metode ceramah yang selama ini diterapkan kurang dapat memberikan kesempatan kepada siswa untuk terlibat dalam proses pembelajaran yang ada. Sebagaimana yang diungkapkan oleh Bermawi Munthe (2009:61), pada dasarnya metode ceramah dapat dilakukan oleh guru yang mempunyai waktu terbatas sedangkan materi yang akan disampaikan banyak. Metode ceramah juga mempunyai keterbatasanketerbatasan tertentu, seperti keberhasilan siswa tidak terukur, perhatian dan motivasi siswa sulit diukur, peran serta siswa dalam pembelajaran rendah, materi kurang terfokus, pembicaraan sering melantur. Penggunaan ceramah secara terus menerus tanpa divariasikan dengan teknik-teknik yang lain dapat menurunkan konsentrasi siswa.

Proses pembelajaran pada hakekatnya mempunyai empat unsur, yaitu persiapan, penyampaian, pelatihan, dan penampilan hasil (http://media.diknas.go.id./media/dokument/50 46.pdf). Keberhasilan dalam pembelajaran membutuhkan keseimbangan empat unsur tersebut. Pada kenyataanya pembelajaran Sosiologi di SMA Yasmida Ambarawa cenderung menekankan unsur penyampaian materi, akibatnya hasil yang dicapai kurang optimal karena siswa cenderung bersifat pasif. Proses ini hanya menekankan pada pencapaian tuntutan kurikulum dan penyampaian tekstual semata daripada mengembangkan kemampuan belajar dan membangun individu. Siswa belum melakukan belajar seperti presentasi, argumentasi, mengemukakan pendapat, menanggapi dan belajar dengan alat bantu berupa rekaman (auditory). Siswa jarang diajak untuk berpikir melalui latihan bernalar, memecahkan masalah, mengkonstruksi, dan menerapkan materi yang disampaikan (intelectually). Tidak adanya pengulangan terhadap materi yang telah disampaikan baik dengan sebuah permainan atau kuis. Berdasarkan hal di atas, guru dan peneliti bersepakat akan mencoba mencari solusi melalui pembaharuan metode mengajar selain metode ceramah yaitu penerapan Model AIR (Auditory, Intellectually, Repetition) dengan Strategi Peninjauan Kembali. Solusi ini penting agar pelaksanaan pembelajaran Sosiologi dapat berjalan dengan lebih baik sehingga dapat memberikan hasil yang optimal.

Berdasar permasalahan-permasalahan yang telah dikemukakan di atas, peneliti mencoba menawarkan salah satu model pembelajaran yang digunakan untuk mengurangi/mengatasi permasalahan yang ada, yaitu menggunakan Model AIR. Model AIR merupakan model pembelajaran yang menganggap bahwa pembelajaran akan efektif jika memperhatikan tiga hal, yakni auditory, yaitu indera digunakan dalam belajar dengan cara mendengarkan, menyimak, berbicara, presentasi, argumentasi, mengemukakan pendapat, dan menanggapi. Intellectually, berpikir melalui latihan bernalar, memecahkan masalah, mengkonstruksi, dan menerapkan, hal ini sejalan dengan pernyataan Dave Meier (dalam Hamruni, 2009: 99). Repetition (pengulangan), pengulangan bisa deterapkan melalui pengerjaan soal, pemberian tugas dan kuis, sehingga pemahaman siswa lebih mendalam dan lebih luas (Mel Silberman, 2009: 340).

Model AIR dengan Strategi Peninjauan Kembali merupakan rangkaian kegiatan belajar yang dilakukan oleh siswa dalam kelompokkelompok tertentu untuk mencapai tujuan pembelajaran yang telah ditentukan. Penerapan model AIR dengan Strategi Peninjauan Kembali diharapkan dapat meningkatkan dan menumbuhkan kreativitas siswa melalui auditory dan intellectually. Prestasi belajar siswa akan terbangun dengan repetition. Oleh karena itu, penerapan model AIR dengan Strategi Peninjauan Kembali ini merupakan salah satu upaya yang tepat untuk mengatasi masalah pembelajaran di SMA Yasmida Ambarawa.

Penelitian yang dilakukan merupakan penelitian tindakan kelas yang diharapkan dapat memperbaiki proses dan hasil pembelajaran.

\section{B. Tujuan}

Sejalan dengan rumusan masalah tersebut maka tujuan penelitian ini adalah Meningkatkan kreativitas dan Keaktifan siswa 
dalam pembelajaran Sosiologi dengan penerapan model AIR dengan Strategi Peninjauan Kembali pada siswa kelas X SMA Yasmida Ambarawa

\section{Metode Penelitian}

Desain penelitian ini adalah menggunakan Classroom Action Research (CAR) yang dikemukakan oleh Kemmis dan Mc. Taggart. Menurut Kemmis dan Mc. Taggart Penelitian Tindakan Kelas dalam pelaksanaannya berupa proses pengkajian berdaur (cyclical) yang terdiri dari empat fase pokok, yaitu:

1. Perencanaan (Planning)

2. Tindakan (Action)

3. Pengamatan (Observation)

4. Refleksi (Reflection)

Penelitian ini dilakukan pada siswa kelas X Yasmida Ambarawa Pringsewu yang berjumlah 26 siswa pada semester ganjil tahun pelajaran 2016/2017. Subyek dari penilitian adalah seluruh siswa kelas $\mathrm{X}$ Yasmida Ambarawa Kab Pringsewu. Objek penelitian ini adalah penerapan Pembelajaran model AIR dengan Strategi Peninjauan Kembali pada materi kelompok social dalam masyarakat dalam Standar Kompetensi dan Kompetensi Dasar (Mengenali dan mengidentifikasi realitas individu, kelompok, dan hubungan sosial di masyarakat).

Teknik pengumpulan data yaitu cara yang digunakan oleh peneliti untuk mengumpulkan data selama proses penelitian dilakukan, serta bagaimana mengetahui hasil belajar siswa. Teknik pengumpulan datanya antara lain:

\section{Observasi \\ Lembar Observasi Keterlaksanaan Pembelajaran}

Tabel 1. Observasi keterlaksanaan Pembelajaran

\begin{tabular}{|c|c|c|c|c|}
\hline \multirow{2}{*}{$\begin{array}{c}\mathrm{N} \\
\mathrm{O}\end{array}$} & \multirow{2}{*}{ Kegiatan } & \multirow{2}{*}{$\begin{array}{l}\text { Aspek yang } \\
\text { diamati }\end{array}$} & \multicolumn{2}{|c|}{ Realisasi } \\
\hline & & & $\mathrm{Ya}$ & Tidak \\
\hline \multirow[t]{4}{*}{1.} & \multirow[t]{4}{*}{$\begin{array}{l}\text { Pendahu } \\
\text { luan }\end{array}$} & $\begin{array}{l}\text { Auditory: } \\
\text { a. Guru memulai } \\
\text { pelajaran } \\
\text { dengan salam. }\end{array}$ & & \\
\hline & & $\begin{array}{l}\text { b.Guru mengajak } \\
\text { siswanya } \\
\text { untuk berdo'a } \\
\text { sebelum } \\
\text { memulai } \\
\text { pelajaran. }\end{array}$ & & \\
\hline & & $\begin{array}{l}\text { c.Guru } \\
\text { memberikan } \\
\text { apersepsi. }\end{array}$ & & \\
\hline & & $\begin{array}{l}\text { d. Guru } \\
\text { menjelaskan } \\
\text { tujuan } \\
\text { pembelajaran }\end{array}$ & & \\
\hline 2. & Inti & Inti : & & \\
\hline
\end{tabular}

\begin{tabular}{|c|c|c|c|c|}
\hline \multirow{2}{*}{$\begin{array}{l}\mathrm{N} \\
\mathrm{O}\end{array}$} & \multirow{2}{*}{ Kegiatan } & \multirow{2}{*}{$\begin{array}{c}\text { Aspek yang } \\
\text { diamati }\end{array}$} & \multicolumn{2}{|c|}{ Realisasi } \\
\hline & & & $\mathrm{Ya}$ & Tidak \\
\hline & $\begin{array}{l}\text { Menggu } \\
\text { nakan } \\
\text { model } \\
\text { AIR } \\
\text { (Auditor } \\
\text { y, } \\
\text { Intellect } \\
\text { ually, } \\
\text { Repetitio } \\
\text { n) }\end{array}$ & 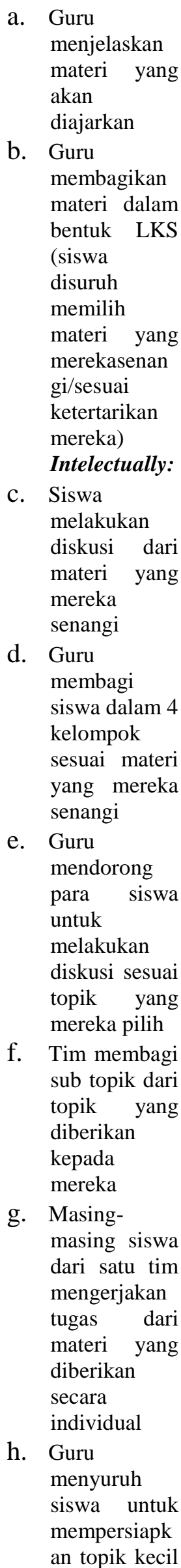 & & \\
\hline
\end{tabular}




\begin{tabular}{|c|c|c|c|c|c|}
\hline \multirow{2}{*}{$\begin{array}{c}\mathrm{N} \\
\mathrm{O}\end{array}$} & \multirow{2}{*}{ Kegiatan } & \multirow{2}{*}{\multicolumn{2}{|c|}{$\begin{array}{c}\text { Aspek yang } \\
\text { diamati }\end{array}$}} & \multicolumn{2}{|c|}{ Realisasi } \\
\hline & & & & $\mathrm{Ya}$ & Tidak \\
\hline & $\begin{array}{l}\text { Mengg } \\
\text { unakan } \\
\text { Strategi } \\
\text { Peninja } \\
\text { uan } \\
\text { Kembal } \\
\text { i }\end{array}$ & $\begin{array}{l}1 . \\
\text { m. } \\
\text { n. } \\
\text { n. }\end{array}$ & $\begin{array}{l}\text { mereka yang } \\
\text { akan } \\
\text { dipresentasik } \\
\text { an kepada } \\
\text { satu tim } \\
\text { Masing- } \\
\text { masing siswa } \\
\text { mempresenta } \\
\text { sikan hasil } \\
\text { tugas } \\
\text { individu } \\
\text { mereka } \\
\text { kepada tim } \\
\text { Guru } \\
\text { mendorong } \\
\text { siswa untuk } \\
\text { memadukan } \\
\text { semua topik } \\
\text { kecil dalam } \\
\text { presentasi tim } \\
\text { Siswa } \\
\text { menulis } \\
\text { jawaban dari } \\
\text { soal yang } \\
\text { diberikan ke } \\
\text { selembar } \\
\text { kertas untuk } \\
\text { dipresentasik } \\
\text { an di depan } \\
\text { kelas } \\
\text { Masing- } \\
\text { masing tim } \\
\text { mempresenta } \\
\text { sikan hasil } \\
\text { kerja mereka } \\
\text { Guru } \\
\text { membahas } \\
\text { bersama } \\
\text { siswa tentang } \\
\text { materi yang } \\
\text { disampaikan } \\
\text { Repetition: } \\
\text { Guru } \\
\text { membagikan } \\
\text { sebuah kartu } \\
\text { indeks } \\
\text { kepada } \\
\text { masing- } \\
\text { masing siswa, } \\
\text { dimana kartu } \\
\text { tersebut berisi } \\
\text { tentang } \\
\text { pertanyaan } \\
\text { atau jawaban } \\
\text { saja } \\
\text { Siswa } \\
\text { mencari } \\
\text { pasangannya } \\
\text { (apabila } \\
\end{array}$ & & \\
\hline
\end{tabular}

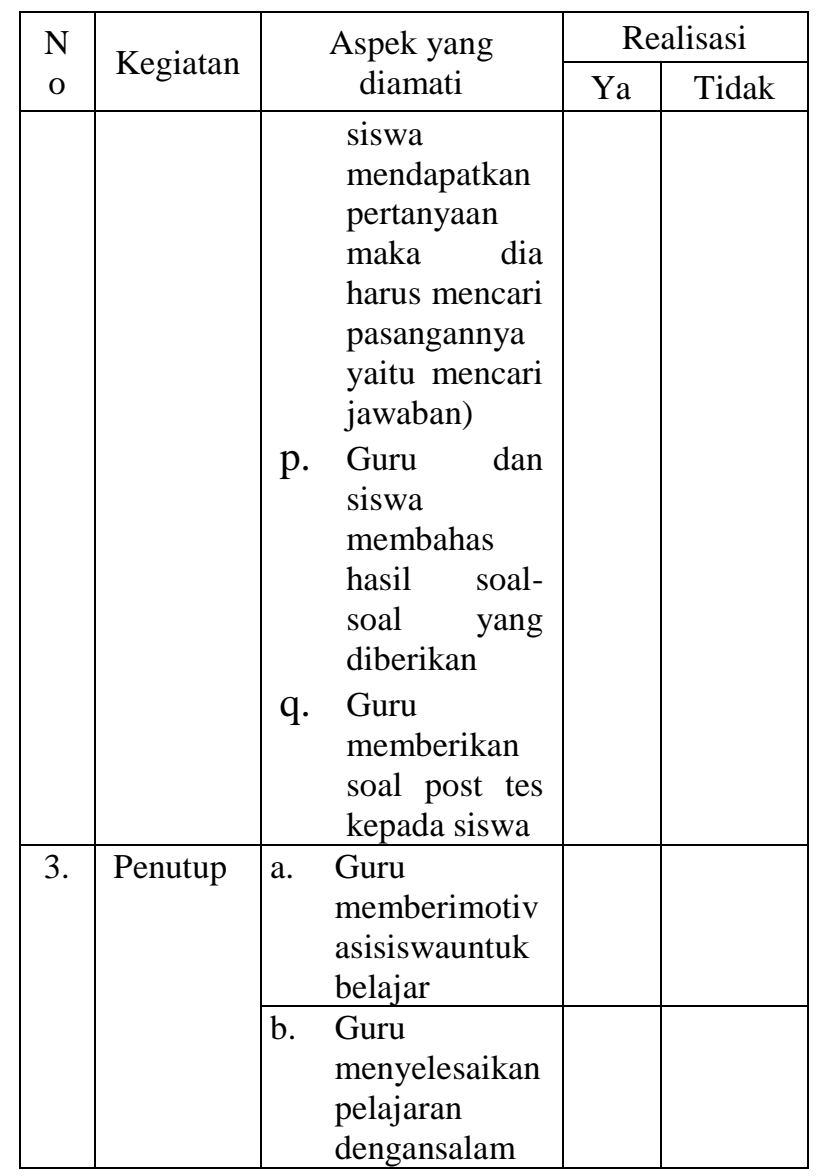

2. Angket

Tabel Kisi-kisi Angket Kreativitas

\begin{tabular}{|c|c|c|c|}
\hline $\begin{array}{l}\mathrm{N} \\
\mathrm{O}\end{array}$ & Indikator & Pernyataan & Arah \\
\hline \multirow[t]{4}{*}{1} & $\begin{array}{l}\text { Kemampuan } \\
\text { untuk } \\
\text { menghasikan } \\
\text { banyak } \\
\text { gagasan. }\end{array}$ & $\begin{array}{l}\text { Saya suka banyak } \\
\text { memberi gagasan }\end{array}$ & Positif \\
\hline & $\begin{array}{l}\text { Kemampuan } \\
\text { untuk } \\
\text { menghasikan } \\
\text { banyak } \\
\text { gagasan. }\end{array}$ & $\begin{array}{l}\text { Saya berani } \\
\text { mengemukakan } \\
\text { gagasan. }\end{array}$ & Positif \\
\hline & $\begin{array}{l}\text { Kemampuan } \\
\text { untuk } \\
\text { menghasikan } \\
\text { banyak } \\
\text { gagasan }\end{array}$ & $\begin{array}{l}\text { Saya takut } \\
\text { mengemukakan } \\
\text { gagasan }\end{array}$ & Negatif \\
\hline & $\begin{array}{l}\text { Kemampuan } \\
\text { untuk } \\
\text { menghasikan } \\
\text { banyak } \\
\text { gagasan. }\end{array}$ & $\begin{array}{l}\text { Saya diam dan } \\
\text { tidak ingin } \\
\text { menyampaikan } \\
\text { gagasan di kelas }\end{array}$ & Negatif \\
\hline 2 & $\begin{array}{l}\text { Kemampuan } \\
\text { untuk } \\
\text { mengemukaka } \\
\text { n barmacam- } \\
\text { macam } \\
\text { pemecahan/pe } \\
\text { ndekatan } \\
\text { terhadap }\end{array}$ & $\begin{array}{l}\text { Saya hanya } \\
\text { menggunakan } \\
\text { satu cara dalam } \\
\text { menyelesaikan/m } \\
\text { engerjakan soal } \\
\text { yang diberikan } \\
\text { guru. }\end{array}$ & Negatif \\
\hline
\end{tabular}




\begin{tabular}{|c|c|c|c|}
\hline $\begin{array}{l}\mathrm{N} \\
\mathrm{O}\end{array}$ & Indikator & Pernyataan & Arah \\
\hline & masalah & & \\
\hline & $\begin{array}{l}\text { Kemampuan } \\
\text { untuk } \\
\text { mengemukaka } \\
\text { n barmacam- } \\
\text { macam } \\
\text { pemecahan/pe } \\
\text { ndekatan } \\
\text { terhadap } \\
\text { masalah. }\end{array}$ & $\begin{array}{l}\text { Saya dapat } \\
\text { mengemukakan } \\
\text { bermacam-macam } \\
\text { pemecahan } \\
\text { terhadap suatu } \\
\text { masalah yang } \\
\text { diberikan. }\end{array}$ & Positif \\
\hline \multirow[t]{2}{*}{3} & $\begin{array}{l}\text { Kemampuan } \\
\text { untuk } \\
\text { menemukan } \\
\text { sesuatu. }\end{array}$ & $\begin{array}{l}\text { Saya tidak dapat } \\
\text { menemukan cara } \\
\text { menyelesaikan } \\
\text { masalah yang } \\
\text { berbeda dengan } \\
\text { teman. }\end{array}$ & Negatif \\
\hline & $\begin{array}{l}\text { Kemampuan } \\
\text { untuk } \\
\text { menemukan } \\
\text { sesuatu. }\end{array}$ & $\begin{array}{l}\text { Saya mampu } \\
\text { menemukan } \\
\text { jawaban dari soal } \\
\text { yang diberikan } \\
\text { guru. }\end{array}$ & Positif \\
\hline \multirow[t]{2}{*}{4} & $\begin{array}{l}\text { Cenderung } \\
\text { memberi } \\
\text { jawaban yang } \\
\text { lebih banyak. }\end{array}$ & $\begin{array}{l}\text { Saya mempunyai } \\
\text { banyak jawaban } \\
\text { dari soal yang } \\
\text { diberikan. }\end{array}$ & Positif \\
\hline & $\begin{array}{l}\text { Cenderung } \\
\text { memberi } \\
\text { jawaban yang } \\
\text { lebih banyak. }\end{array}$ & $\begin{array}{l}\text { Saya merasa puas } \\
\text { ketika sudah } \\
\text { menemukan } \\
\text { jawaban sehingga } \\
\text { saya tidak } \\
\text { berusaha mencari } \\
\text { jawaban dengan } \\
\text { cara yang lain. }\end{array}$ & Negatif \\
\hline \multirow[t]{2}{*}{5} & $\begin{array}{l}\text { Mampu } \\
\text { menguraikan } \\
\text { sesuatu secara } \\
\text { terperinci } \\
\end{array}$ & $\begin{array}{l}\text { Saya terbiasa } \\
\text { menyelesaikan } \\
\text { soal secara } \\
\text { terperinci. }\end{array}$ & positif \\
\hline & $\begin{array}{l}\text { Mampu } \\
\text { menguraikan } \\
\text { sesuatu secara } \\
\text { terperinci. }\end{array}$ & $\begin{array}{l}\text { Saya tidak bisa } \\
\text { menemukan } \\
\text { jawaban dari soal } \\
\text { yang diberikan } \\
\text { guru. }\end{array}$ & Negatif \\
\hline \multirow[t]{3}{*}{6} & $\begin{array}{l}\text { Menanggapi } \\
\text { pertanyaan } \\
\text { yang diajukan. }\end{array}$ & $\begin{array}{l}\text { Saya hanya diam } \\
\text { saja, ketika guru } \\
\text { memberikan } \\
\text { pertanyaan. }\end{array}$ & Negatif \\
\hline & $\begin{array}{l}\text { Menanggapi } \\
\text { pertanyaan } \\
\text { yang diajukan. }\end{array}$ & $\begin{array}{l}\text { Apabila ada } \\
\text { teman bertanya } \\
\text { kepada saya, saya } \\
\text { menjawab/menan } \\
\text { ggapinya. }\end{array}$ & Positif \\
\hline & $\begin{array}{l}\text { Menanggapi } \\
\text { pertanyaan } \\
\text { yang diajukan. }\end{array}$ & $\begin{array}{l}\text { Saya dapat } \\
\text { menanggapi } \\
\text { pertanyaan dari } \\
\text { guru }\end{array}$ & Positif \\
\hline \multirow[t]{2}{*}{7} & $\begin{array}{l}\text { Mempunyai } \\
\text { banyak } \\
\text { pertanyaan. }\end{array}$ & $\begin{array}{l}\text { Saya tidak } \\
\text { bertanya, ketika } \\
\text { teman presentasi } \\
\text { di depan kelas. }\end{array}$ & Negatif \\
\hline & Mempunyai & Saya mempunyai & Positif \\
\hline
\end{tabular}

\begin{tabular}{|c|l|l|l|}
\hline $\begin{array}{c}\mathrm{N} \\
\mathrm{o}\end{array}$ & \multicolumn{1}{|c|}{ Indikator } & \multicolumn{1}{|c|}{ Pernyataan } & Arah \\
\hline & banyak & banyak & \\
& pertanyaan. & $\begin{array}{l}\text { pertanyaan ketika } \\
\text { saya belum faham } \\
\text { materi yang } \\
\text { disampaikan guru. }\end{array}$ & \\
\hline
\end{tabular}

Tabel 3. Lembar observasi Kreatifitas siswa

\begin{tabular}{|l|l|ll|l|l|l|}
\hline No & $\begin{array}{c}\text { Aspek yang } \\
\text { diamati }\end{array}$ & \multicolumn{2}{|c|}{ Indikator } & \multicolumn{3}{|c|}{ Realisasi } \\
\cline { 3 - 7 } 1 & Keaktifan & $\begin{array}{l}\text { a. } \\
\text { Siswa } \\
\text { bertanya } \\
\text { kepada guru } \\
\text { bila ada } \\
\text { materi yang } \\
\text { tidakdifaha } \\
\text { mi }\end{array}$ & 1 & 2 & 3 & 4 \\
\hline & & & & & \\
\hline
\end{tabular}

b. Siswa

menjawab

pertanyaan

dari guru.

c. Siswa

mencatat

poin-poin

penting.

d. Siswa

mengemuka

kan

gagasan/pen

dapatnya

e. Siswadapat

mengajukan

banyak

pertanyaan

kepada

guru.

f. Siswa

dapat

menyelesai

kan

masalah

dengan

caranya

sendiri.

g. Siswa

dapat

menyelesai

kan

masalah

dengan

lebih dari

satu cara.

h. Siswa

mampu

mengoreks

i suatu

jawaban 


\begin{tabular}{|c|c|c|c|c|c|c|c|}
\hline \multirow{7}{*}{ No } & \multirow{7}{*}{$\begin{array}{c}\text { Aspek yang } \\
\text { diamati }\end{array}$} & \multirow{2}{*}{\multicolumn{2}{|c|}{ Indikator }} & \multicolumn{4}{|c|}{ Realisasi } \\
\hline & & & & 1 & 2 & 3 & 4 \\
\hline & & & $\begin{array}{l}\text { benar atau } \\
\text { salah. }\end{array}$ & & & & \\
\hline & & & $\begin{array}{l}\text { Siswa } \\
\text { mampu } \\
\text { menerapka } \\
\text { n konsep } \\
\text { dalam } \\
\text { contoh } \\
\text { pemecahan } \\
\text { masalah. }\end{array}$ & & & & \\
\hline & & & $\begin{array}{l}\text { Siswa } \\
\text { dapat } \\
\text { menyelesai } \\
\text { kan soal } \\
\text { dengan } \\
\text { menerapka } \\
\text { n apa yang } \\
\text { sampaikan } \\
\text { guru }\end{array}$ & & & & \\
\hline & & & $\begin{array}{l}\text { Siswa } \\
\text { dapat } \\
\text { menjawab } \\
\text { soal secara } \\
\text { rinci dan } \\
\text { lengkap. }\end{array}$ & & & & \\
\hline & & & $\begin{array}{l}\text { Siswa } \\
\text { dapat } \\
\text { memberika } \\
\text { n jawaban } \\
\text { secara } \\
\text { cepat dan } \\
\text { tepat. }\end{array}$ & & & & \\
\hline
\end{tabular}

\section{Kisi-kisi kreatifitas siswa}

\begin{tabular}{|c|c|c|c|}
\hline $\begin{array}{l}\mathbf{N} \\
\text { o. }\end{array}$ & $\begin{array}{c}\text { Aspek } \\
\text { yang } \\
\text { diteliti }\end{array}$ & Indikator & $\begin{array}{l}\text { Nomo } \\
\mathbf{r} \\
\text { Perta } \\
\text { nyaan }\end{array}$ \\
\hline \multirow[t]{2}{*}{1.} & \multirow[t]{2}{*}{$\begin{array}{l}\text { Kerjasam } \\
\text { a }\end{array}$} & $\begin{array}{l}\square \text { Berdiskusi dengan } \\
\text { teman }\end{array}$ & \multirow{2}{*}{$\begin{array}{l}3,4,6, \\
7\end{array}$} \\
\hline & & $\begin{array}{c}\text { Kompak dalam } \\
\text { pelaksanaan kegiatan }\end{array}$ & \\
\hline \multirow[t]{5}{*}{2.} & \multirow{5}{*}{$\begin{array}{l}\text { Keserius } \\
\text { an dalam } \\
\text { Belajar }\end{array}$} & $\begin{array}{l}\text { Bertanya dan } \\
\text { menjawab pertanyaan }\end{array}$ & \multirow{5}{*}{$\begin{array}{l}1,5,8, \\
12,13, \\
15\end{array}$} \\
\hline & & $\begin{array}{l}\text { Membaca dan } \\
\text { mencatat }\end{array}$ & \\
\hline & & $\square \quad$ Memberi pendapat & \\
\hline & & $\square \quad$ Mencari literatur & \\
\hline & & $\square \quad$ Mengerjakan tugas & \\
\hline 3. & $\begin{array}{l}\text { Tanggun } \\
\text { g Jawab }\end{array}$ & $\begin{array}{l}\text { Menjaga ketertiban } \\
\text { kelas }\end{array}$ & $\begin{array}{l}9,11,1 \\
2\end{array}$ \\
\hline
\end{tabular}

\begin{tabular}{|c|c|c|c|}
\hline & & $\begin{array}{l}\quad \text { Menjaga buku } \\
\text { sumber ataupun media } \\
\text { yang digunakan }\end{array}$ & \\
\hline \multirow[t]{2}{*}{4.} & \multirow[t]{2}{*}{ Perasaan } & $\square \quad$ Suka & \multirow{2}{*}{14} \\
\hline & & $\square \quad$ Gembira & \\
\hline \multirow[t]{2}{*}{5.} & \multirow[t]{2}{*}{$\begin{array}{l}\text { Pengama } \\
\tan \end{array}$} & $\square \quad$ Melihat & \multirow{2}{*}{2} \\
\hline & & $\square \quad$ Mendengar & \\
\hline & & umlah Soal & 15 \\
\hline
\end{tabular}

\section{Angket Keaktifan Belajar Sosiologi Siswa}

1. Setiap ada jam pelajaran Sosiologi, saya mengikuti dengan serius
a. Selalu
b. Sering
c. Kadang - Kadang
d. Tidak Pernah

2. Saya mendengarkan dan memperhatikan, apabila guru sedang menerangkan materi.
a. Selalu
b. Sering
c. Kadang - Kadang
e. Tidak Pernah

3. Saya selalu aktif dalam kelompok saat memecahkan masalah yang diberikan oleh guru.
a. Selalu
b. Sering
c. Kadang - Kadang
d. Tidak Pernah

4. Saya berusaha bertanya kepada teman yang telah paham apabila saya mengalami kesulitan dalam mengerjakan soal-soal sosiologi.
a. Selalu
b. Sering
c. Kadang - Kadang
d. Tidak Pernah

5. Saya berusaha mengeluarkan pendapat untuk menjawab pertanyaan guru saat pelajaran berlangsung.
a. Selalu
b. Sering
c. Kadang - Kadang
d. Tidak Pernah

6. Sewaktu saya mengeluarkan pendapat saya juga memberi kesempatan pada teman yang lain untuk mengeluarkan pendapatnya.
a. Selalu
b. Sering
c. Kadang - Kadang
d. Tidak Pernah

7. Saya mencoba ikut menjawab pertanyaan saat ada teman yang bertanya.

a. Selalu 

b. Sering
c. Kadang - Kadang
d. Tidak Pernah

8. Saya berusaha mencari tambahan materi pelajaran sosiologi selain dari buku paket yang diberikan Bapak/Ibu guru.
a. Selalu
b. Sering
c. Kadang - Kadang
d. Tidak Pernah

9. Saya menyampul buku paket, buku catatan, dan buku latihan sosiologi dengan rapi.
a. Selalu
b. Sering
c. Kadang - Kadang
d. Tidak Pernah

10. Saya menjaga kartu soal dan kartu jawaban agar tetap dalam keadaan baik.
a. Selalu
b. Sering
c. Kadang - Kadang
d. Tidak Pernah

11. Saya membaca buku paket sosiologi pada malam sebelum pelajaran sosiologi dimulai esok paginya di sekolah.
a. Selalu
b. Sering
c. Kadang - Kadang
d. Tidak Pernah

12. Saya menjaga ketertiban saat belajar sosiologi di dalam kelas.
a. Selalu
b. Sering
c. Kadang - Kadang
d. Tidak Pernah

13. Saya mencatat setiap materi yang diberikan guru di dalam buku catatan dengan rapi.
a. Selalu
b. Sering
c. Kadang - Kadang
d. Tidak Pernah

14. Mengikuti pelajaran sosiologi membuat saya gembira.
a. Selalu
b. Sering
c. Kadang - Kadang
d. Tidak Pernah

15. Saya mengerjakan tugas dengan sungguh sungguh.
a. Selalu
b. Sering
c. Kadang - Kadang
d. Tidak Pernah

\section{Pembahasan}

\section{Kreativitas Siswa}

Hasil penelitian menggunakan model pembelajaran AIR dengan Strategi Peninjauan Kembali menunjukkan bahwa kreativitas siswa mengalami peningkatan. Peningkatan kreativitas ini dapat dilihat dari hasil angket siklus I, dan angket siklus II. Hasil peningkatan kreativitas angket tersebut juga didukung dengan hasil observasi kreativitas siswa.

Kreativitas dalam penelitian ini difokuskan pada kemampuan untuk menghasilkan banyak gagasan, kemampuan untuk mengemukakan berbagai macam pemecahan masalah, kemampuan untuk menemukan sesuatu, cenderung memberikan jawaban yang lebih banyak, mampu menguraikan sesuatu secara terperinci, mampu menanggapi pertanyaan yang diajukan, dan mempunyai banyak pertanyaan.

Berdasarkan lembar observasi terlihat bahwa kreativitas siswa dari siklus I sampai siklus II mengalami peningkatan. Peningkatan ini terjadi ketika telah diterapkannya model pembelajaran AIR dengan Strategi Peninjuan Kembali. Hasil pengisian angket kreativitas siswa dapat dilihat rata-rata hasil pengisian angket setiap siklus. Berikut analisis perhitungannya pada siklus I dan II.

Tabel 17. Hasil Analisis Angket Kreativitas Siswa Pada Siklus I dan II.

\begin{tabular}{|l|c|c|c|c|}
\hline \multirow{2}{*}{ Indikator } & \multicolumn{2}{|c|}{ Siklus I } & \multicolumn{2}{c|}{ Siklus II } \\
\cline { 2 - 5 } & $\%$ & Kualifikasi & $\%$ & Kualifikasi \\
\hline $\begin{array}{l}\text { Kemampuan } \\
\text { menghasilkan } \\
\text { banyak } \\
\text { gagasan. }\end{array}$ & 59.05 & Rendah & 75.29 & Sedang \\
\hline $\begin{array}{l}\text { Kemampuan } \\
\text { mengemukakan } \\
\text { bemacam- } \\
\text { macam } \\
\text { pemecahan } \\
\text { terhadap } \\
\text { masalah }\end{array}$ & 61.30 & Sedang & 77.88 & Sedang \\
\hline $\begin{array}{l}\text { Kemampuan } \\
\text { menemukan } \\
\text { sesuatu }\end{array}$ & 59.52 & Rendah & 75 & Sedang \\
\hline $\begin{array}{l}\text { Cenderung } \\
\text { memberikan } \\
\text { jawaban lebih } \\
\text { banyak }\end{array}$ & 58.92 & Rendah & 75.07 & Sedang \\
\hline $\begin{array}{l}\text { Mampu } \\
\text { menguraikan } \\
\text { jawaban secara } \\
\text { terperinci }\end{array}$ & 57.14 & Rendah & 75.85 & Sedang \\
\hline $\begin{array}{l}\text { Menanggapi } \\
\text { pertanyaan } \\
\text { yang diajukan }\end{array}$ & 61.90 & Sedang & 76 & Sedang \\
\hline $\begin{array}{l}\text { Mempunyai } \\
\text { banyak } \\
\text { pertanyaan }\end{array}$ & 59.69 & Rendah & 76.58 & Sedang \\
\hline Rata-rata & Rendah & 80.95 & Tinggi \\
\hline Suber Hang & & & & \\
\hline
\end{tabular}

Sumber: Hasil Angket Kreativitas Siswa 
Berdasarkan tabel di atas dapat kita lihat bahwa terjadi peningkatan frekuensi siswa dalam aspek kreativitasnya dari siklus I ke siklus II. Secara umum menunjukkan bahwa setiap indikator kreativitas yang ada mengalami peningkatan walau hanya pada tingkat sedang dan hanya satu indikator yang menunjukkan pada tingkat tinggi yaitu mempunyai banyak pertanyaan. Indikator "mempunyai banyak pertanyaan" menjadi yang tertinggi diantara indikator yang lain menunjukkan respon yang baik oleh siswa terhadap materi yang telah disampaikan. Ini menunjukkan bahwa siswa sudah mampu mengolah dan menerima rangsangan.

Secara keseluruhan hasil dari setiap indikator pada siklus I dan II dapat dilihat dalam garafik perbandingan hasil kreativitas siswa di bawah ini.

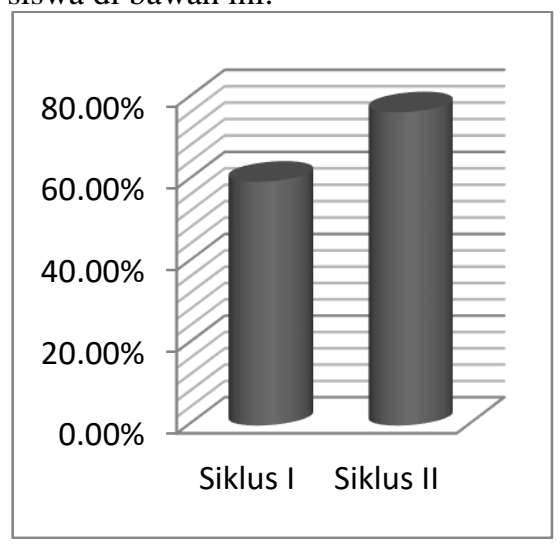

Gambar 18. Grafik Perbandingan Kreativitas Siklus I Dan Siklus II

Pada siklus yang pertama angket kreativitas siswa mencapai $59,69 \%$ yang mempunyai kualifikasi rendah, pada siklus yang kedua kreativitas siswa mencapai $76.58 \%$ yang mempunyai kualifikasi sedang. Hasil ini menunjukkan adanya peningkatan kreativitas siswa dari siklus I ke siklus II yaitu sebesar 16.88\%. Dari sini, maka peneliti menyimpulkan bahwa dengan menggunakan model pembelajaran AIR dengan Strategi Peninjauan Kembali dapat meningkatkan kreativitas siswa.

Berdasarkan data-data yang telah dideskripsikan di atas, maka peneliti menyimpulkan bahwa dari semua hasil yang diperoleh tersebut dapat menjawab permasalahan yang diajukan dalam penelitian yaitu dengan menggunakan pembelajaran model dengan Strategi Pennjauan Kembali kreativitas siswa dapat meningkat.

\section{Keaktifan Siswa}

Setiap siklus peneliti mengadakan observasi tentang keaktifan siswa dalam kelas. Angket kraetifitas siswa digunakan untuk mengetahui tingkat penguasaan materi dalam satu siklus dan hasil belajar siswa dalam pembelajaran Sosiologi. Penggunaan model pembelajaran AIR dengan Strategi Peninjauan Kembali dapat meningkatkan keaktifan siswa. Hal tersebut dapat dilihat dari lembar observasi keaktifan di setiap siklusnya. Hasil rata-rata skor keaktifan siklus dapat digunakan sebagai alat untuk untuk mengukur keaktifan siswa terhadap pelajaran Sosiologi. Hasil rata-rata skor keaktifan dapat dilihat pada tabel berikut:

\begin{tabular}{|c|c|c|c|c|c|}
\hline $\begin{array}{l}\text { Aspek } \\
\text { yang } \\
\text { diteliti }\end{array}$ & Indikator & $\begin{array}{l}\text { Siklus } \\
\text { I }\end{array}$ & Kualifikasi & $\begin{array}{l}\text { Siklus } \\
\text { II }\end{array}$ & Kualifikasi \\
\hline \multirow{2}{*}{ Kerjasama } & $\begin{array}{l}\text { Berdiskusi } \\
\text { dengan teman }\end{array}$ & $69 \%$ & Rendah & $86 \%$ & Tinggi \\
\hline & $\begin{array}{l}\text { Kompak dalam } \\
\text { pelaksanaan } \\
\text { kegiatan }\end{array}$ & $59 \%$ & Rendah & $80 \%$ & Tinggi \\
\hline \multirow{5}{*}{$\begin{array}{l}\text { Keseriusan } \\
\text { dalam } \\
\text { Belajar }\end{array}$} & $\begin{array}{l}\text { Bertanya dan } \\
\text { menjawab } \\
\text { pertanyaan }\end{array}$ & $63 \%$ & Sedang & $74 \%$ & Sedang \\
\hline & $\begin{array}{l}\text { Membaca dan } \\
\text { mencatat }\end{array}$ & $55 \%$ & Rendah & $84 \%$ & Tinggi \\
\hline & $\begin{array}{l}\text { Memberi } \\
\text { pendapat }\end{array}$ & $55 \%$ & Sedang & $73 \%$ & Sedang \\
\hline & $\begin{array}{l}\text { Mencari } \\
\text { literatur }\end{array}$ & $63 \%$ & Sedang & $85 \%$ & Tinggi \\
\hline & $\begin{array}{l}\text { Mengerjakan } \\
\text { tugas }\end{array}$ & $55 \%$ & Rendah & $79 \%$ & Sedang \\
\hline \multirow[b]{2}{*}{$\begin{array}{l}\text { Tanggung } \\
\text { Jawab }\end{array}$} & $\begin{array}{l}\text { Menjaga } \\
\text { ketertiban kelas }\end{array}$ & $64 \%$ & Sedang & $75 \%$ & Sedang \\
\hline & $\begin{array}{l}\text { Menjaga buku } \\
\text { sumber ataupun } \\
\text { media yang } \\
\text { digunakan }\end{array}$ & $63 \%$ & Sedang & $77 \%$ & Sedang \\
\hline \multirow{2}{*}{ Perasaan } & Suka & $63 \%$ & Sedang & $83 \%$ & Tinggi \\
\hline & Gembira & $63 \%$ & Sedang & $83 \%$ & Tinggi \\
\hline \multirow{2}{*}{ Pengamatan } & Melihat & $64 \%$ & Sedang & $84 \%$ & Tinggi \\
\hline & Mendengar & $66 \%$ & Sedang & $87 \%$ & Tinggi \\
\hline \multicolumn{2}{|c|}{ Jumlah Soal } & $62 \%$ & Sedang & $81 \%$ & Tinggi \\
\hline
\end{tabular}

Sumber: Hasil Angket Keaktifan Siswa

Tabel di atas menunjukkan bahwa terjadi peningkatan keaktifan siswa dalam aspek keaktifan dari siklus I ke siklus II. Secara umum menunjukkan bahwa setiap indikator keaktifan yang ada mengalami peningkatan walau masih ada 5 indikator yang berada pada tingkat sedang yaitu bertanya dan menjawab pertanyaan, memberi pendapat, mengerjakan tugas, menjaga ketertiban kelas, menjaga buku sumber ataupun media yang digunakan. Hal ini 
menunjukkan bahwa indikator yang lain menunjukkan respon yang baik oleh siswa sehingga berimplikasi terhadap tingkat keaktifan siswa di kelas.

Tabel 18. Hasil Rata-Rata, tertinggi dan terendah dari Persentase keaktifan Siswa

\begin{tabular}{|l|c|c|}
\hline \multicolumn{2}{|c|}{ Skor } & \multicolumn{2}{c|}{ Siklus } \\
\cline { 2 - 3 } & I & II \\
\hline $\begin{array}{l}\text { Rata-rata skor } \\
\text { Keaktifan }\end{array}$ & $62 \%$ & $81 \%$ \\
\hline $\begin{array}{l}\text { Skor minimal } \\
\text { Keaktifan }\end{array}$ & $55 \%$ & $73 \%$ \\
\hline $\begin{array}{l}\text { Skor maksimal } \\
\text { Keaktifan }\end{array}$ & $69 \%$ & $87 \%$ \\
\hline
\end{tabular}

Sumber: Hasil angket keaktifan Siswa

Dari tabel di atas terlihat rata-rata kelas juga mengalami peningkatan dari siklus I ke siklus II. Secara garis besar keaktifan siswa sudah mengalami peningkatan hal ini bisa dilihat dari rata-rata kelas, skor minimal dan skor maksimal siswa yang mengalami peningkatan. Dengan kata lain berarti sudah banyak siswa yang mengalami peningkatan dalam segi keaktifan.

\section{Daftar Pustaka}

Abu Ahmadi \& Nur Uhbiyati. (2001). Ilmu Pendidikan. Jakarta : PT. Rineka Putra.

Amal abdul Salam Alhalili. (2005). Mengembangkan Kreativitas Anak. Jakarta : Pustaka Alkautsar.

Amalina \& Siswono. 2016. Investigasi Kemampuan Berpikir Kreatif Siswa Dalam Pengajuan Masalah Matematika Jurnal Ilmiah Pendidikan Matematika Volume 2 No.5 Tahun 2016 ISSN : 2301-9085

Beni Ambarjaya. (2008). Model-model Pembelajaran Kreatif. Bandung : Tinta Emas Publishing.

Bermawi Munthe. (2009). Desain Pembelajaran. Yogyakarta : Pustaka Insani Madani.

Bintarto dan Surastopo Hadisumarno. (1987). Metode Analisa Geografi. Jakarta: LP3S.

Dasim Budimansyah,dkk. (2009). Pembelajaran Aktif, Kreatif, Efektif, dan Menyenangkan. Bandung : PT. Genesindo.

Emi Naziatul Mawaddah. (2009). Kreativitas dan Hasil Belajar Matematika dalam Model Pembelajaran Auditory Intellectually Repetition (AIR) di SMP Negeri 3 Batu. Skripsi. Malang:Fakultas MIPA UMM Malang.
Hamruni. (2009). Strategi dan model-model pembelajaran aktif menyenangkan. Yogyakarta : Fak. Tarbiyah UIN.

Hamzah B. Uno. (2010). Model Pembelajaran, Menciptakan Proses Belajar Mengajar Yang Kreatif dan Efektif. Jakarta: PT. Bumi Aksara.

Herman, T. 2007. Pembelajaran Berbasis Masalah untuk Meningkatkan Kemampuan Berpikir Matematis Tingkat Tinggi Siswa Sekolah Menengah Pertama. Educationist 1(1): 47-56.

Johnson B. Elaine. Contextual Teaching Learning: Menjadikan Kegiatan Belajar Mengajar Mengasyikkan Dan Bermakna. Bandung: MLC.

Jugiyanto. (2007). Filosofi, Pendekatan, dan Penerapan Pembelajaran Metode Kasus. Yogyakarta : Andi Offset.

Monty Satiadarma \& Fidelis Waruwu. (2003). Mendidik Kecerdasan. Jakarta : Pustaka Populer Obor.

Nana Sudjana. (2000). Dasar-dasar Proses Belajar Mengajar. Bandung: PT. Sinar Baru Algensindo.

Nasution. (2008). Asas-asas Kurikulum. Jakarta: Bumi Aksara.

Ningrum, P. 2016. Meningkatkan keaktifan dan kemampuan berpikir kreatif melalui Pembelajaran kolaboratif berbasis masalah materi kelarutan Dan hasil kali kelarutan (ksp) siswa kelas xi SMA Negeri 10 Semarang Jurnal Pendidikan Sains Universitas Muhammadiyah Semarang. Volume 04 Nomor 01 Maret 2016

Nursyid Sumaatmadja. (2001). Metedologi Pengajaran Geografi. Jakarta : Bumi Aksara.

Prihantoro. 2012. Peningkatan kinerja sumber daya manusia melalui motivasi, Disiplin, lingkungan kerja, dan komitmen (studi kasus madrasah di lingkungan yayasan salafiyah, kajen, margoyoso, pati). Vol. 8, no.2, maret 2012-Agustus 2012.

Rusman. (2011). Model-model Pembelajaran. Jakarta: PT. Raja Grafindo Persada.

Sahala, S dan Samad, A. 2010. Penerapan Model Pembelajaran Berbasis Masalah dalam Pembiasan Cahaya Pada Lensa Terhadap Hasil Belajar Siswa di Kelas VIII SMP Negeri 5 Ketapang. Jurnal Matematika dan IPA, 1(2): 12-25.

Sardiman A.M. (2007). Interaksi dan motivasi belajar mengajar. Jakarta : PT. Raja Grafindo Persada.

Sofan Amri \& Iif khoiru Ahmadi. (2010). Kontruksi Pengembangan Pembelajaran. Jakarta : PT. Prestasi Pustakaraya. 
Sudjana. (2005). Strategi Pembelajaran. Bandung: Falah Production.

Sugiyono. (2007). Metode Penelitian

Pendidikan pendekatan kuantitatif,

kualitatif dan $R$ \& D. Bandung :

Alfabeta. 